Research Article

\title{
Investigating the Complex Relationship between Financial Performance and Company's Green Behavior: A Comparative Analysis
}

\author{
Wenyao Zhang $\mathbb{D}^{1},{ }^{1}$ Ruzhi Xu $\mathbb{D}^{1},{ }^{1}$ and Lu Wang $\mathbb{B}^{2}$ \\ ${ }^{1}$ School of Finance, Qilu University of Technology (Shandong Academy of Sciences), Jinan, Shandong 250353, China \\ ${ }^{2}$ School of Information Management and Engineering, Zhejiang University of Finance and Economics, Hangzhou, \\ Zhejiang 310018, China
}

Correspondence should be addressed to Lu Wang; wanglu_hit@126.com

Received 13 March 2021; Revised 7 May 2021; Accepted 1 June 2021; Published 19 June 2021

Academic Editor: Guangdong Wu

Copyright ( 12021 Wenyao Zhang et al. This is an open access article distributed under the Creative Commons Attribution License, which permits unrestricted use, distribution, and reproduction in any medium, provided the original work is properly cited.

Under the new normal of economy, the relationship between economic benefits and company's environmental behavior (green behavior) has long been the focus of scholars' research, but less attention has been paid to the effect of financial performance on company's green behavior in China as a developing country. Thus, by adopting a mixed methodology, we conduct a quantitative study by selecting 228 companies as samples with good and poor green behavior for comparative analysis, followed by a qualitative study of 20 specific cases, to analyse the complex relationship mechanism of how financial performance in terms of business solvency, profitability, and development ability affect company's green behavior. The results indicate that business solvency, profitability, and development ability are strongly associated with company's green behavior, respectively. This study contributes to the green behavior literature.

\section{Introduction}

In recent years, green development has become an important issue of companies given the growing public concern for environmental protection issues $[1,2]$. As the most important participants in economic activities, companies tend to ignore environmental pollution while actively pursuing economic benefits. They will be alert to environmental protection only when problems arise. So, is economic benefit necessarily contradictory to company's green behavior? In fact, there has been no answer given to this issue.

Extant studies try to elaborate the relationship between corporate financial and environmental performance and its nature in mature market economies from various theoretical perspectives [3]. For instance, drawing on the resourcebased theory, $\mathrm{Wu}$ et al. evidenced that a firm's sustainable efficiency and competitive advantage rely on its capabilities and diverse resources which cannot be replicated by its competitors [4]. Utilizing the stakeholder theory, El Ghoul et al. believed that a firm who has better corporate environmental performance is provided with a lower cost of capital since it decreases business risk by forming stakeholder satisfaction and goodwill [5]. In addition, most other studies concentrate on unidirectional causality of measuring the impact of corporate environmental performance on financial performance $[3,6]$. However, slack resource theory suggests that business organisations can opt for better environmental performance if their resources available are abundant. That is because improving environmental practices is costly, so some companies have to ensure first their financial situation before inputting resources in efficient environmental practices. Consequently, causation in such a situation suggests improved financial performance results in better corporate environmental behavior [3].

Furthermore, more attention has been paid to the studies of corporate environmental behavior and green behavior. Yu and Zhu [7] analyzed the influence of policy mechanisms, public preferences, and profit motives on the 
implementation of positive environmental behavior by companies. Zhou [8] constructed a functional system inclusive of corporate environmental behavior, its driving force, and its performance, in a way to quantitatively illustrate the path and effect of different factors that affect corporate environmental behavior, and pointed out the fact that this behavior is beneficial to improving corporate performance. Meanwhile, corporate green behavior refers to an activity or a series of positive plans conducted by companies in terms of resources and environmental protection, which is equivalent to environmental behavior in connotation. Different scholars have explained that stakeholder pressure promotes corporate's green behavior by affecting the implementation of corporate forward-looking strategies. For example, Greenley and Foxall [9] first proposed the concept of stakeholder orientation and perfected the stakeholder orientation model with Europe as the background on the basis of market orientation and argued that stakeholder orientation is an important choice for companies to promote environmental protection. Schaltegger et al. [10] examined that the effective participation of stakeholders in monitoring corporate environmental behavior can prompt companies to respond positively to environmental issues.

In spite of the above academic achievements, there is no consistent conclusion that clearly answers the questions raised above, with little attention paid to the impact of financial performance on corporate's green behavior. Given that financial performance determines the arteries and veins of economic development, it will inevitably promote or restrict the development of corporate green behavior, so this study reveals the internal complex mechanism of how financial performance affects company's green behavior. Specifically, this study employs the support vector machine (SVM) as the mathematical measurement model as it has been generally used in researches dealing with financial indicators due to its good judgment confirmed on the performance of financial indicators $[11,12]$. By adopting this mathematical measurement model, taking companies with good and bad green behavior as samples for a comparative analysis, this article selects three financial indicators of business solvency, profitability, and development ability as they are key measures to represent companies' economic level and operating status, thereby revealing their complex relationship with company's green behavior because environmental management in developing counties is less mature than in developed countries [13].

This article is organized as follows. The following section discusses theoretical hypotheses and a mathematical measurement model, followed by research methodology and data analysis and results. Further, this article provides the discussion and conclusion in terms of key findings and implications for theory and practice.

\section{Theoretical Hypotheses}

In this section, we develop arguments for hypotheses about the complex relationships that tap into environment, economy, and society aspects among variables.
2.1. Business Solvency and Green Behavior. Business solvency is a company's ability to repay short-term and long-term debts with its assets and is an important symbol to reflect the company's stable financial conditions and operating ability. Moreover, the strength of business solvency is taken as an important yardstick to measure financial status and economic power [13]. The company with strong business solvency will be more favoured by insurance companies and other financial companies if it effectively implements environmental management behavior [14]. From the angle of economic and environmental benefits, Khanna [15] pointed out that many current assessment agencies incorporate environmental protection policies and company's environmental behavior into the scope of risk assessment. Then, company's environmental expenditure behavior makes for attracting external investors to expand the size and strength of the economy and thus generate positive effect to their development. In other words, the company with strong solvency engaged in green behavior can help reduce financing cost and broaden its chance of development [16].

In other words, economic ability is increased; then, it will naturally enhance the company's business solvency, so that the company is more willing to engage in different environmental practices to establish favourable relationship with stakeholders (e.g., suppliers, distributors, and customers) by addressing their environmental concerns. From the angle of social and environmental benefits, the company with strong business solvency usually has stable operation ability and can timely repay the loans owed when funds are returned. It has prestige and credibility in stakeholders. Such a company has a sense of social ethics and pays attention to maintaining a positive corporate image. Therefore, it will actively implement green practices to safeguard the welfare of the society where people live.

With the deepening of environmental protection behavior, such companies will gain more and more social recognition, including a variety of financial institutions and partners, which is conducive to improving the company's financial indicators and improving its solvency. Following that, we believe the company with strong business solvency can gain stronger competitive advantage in environmentally friendly protection with a result of financial and social performance improved. Therefore, we propose the following hypothesis:

H1: business solvency is strongly associated with company's green behavior.

2.2. Profitability and Green Behavior. Profitability is understood as the capital or capital appreciation ability manifested usually as the level and amount of company's earnings in some period, so it is defined as a company's ability to gain profits [17]. The company with strong profitability usually produces products or provides services that are loved by consumers and win broad market recognition and wins consumers' increasing recognition of green products. Nowadays, as citizens' awareness of social responsibility and safety improves, consumers are increasingly advocating green consumption; thereby, they would 
like to pay environmental protection premium for products that have fulfilled their environmental responsibilities [18].

In order to further gain more market share, the company's profitability can impact the investment of environmental initiatives with better financial status as such companies enable better environmental initiatives than that with poor status [19]. The company with high profitability will pay more attention to reducing environmental pollution and thus will increase investment in equipment and technology and strategies, shifting attention to pollution prevention and control in the production process; doing such can realize energy conservation and emission reduction and reduced costs and facilitates effective improvement in green productivity; in this sense, the company is more willing to nurture green behavior and also improve the company's profitability by more tangible economic returns acquired.

Additionally, the company with strong profitability is a large-scale company with certain scale, whose organizational atmosphere is created to promote employees' green behavior. Specifically, the company invests in environmental protection budget to launch employee training programs and research and development activities with regard to environmental issues and forward the company's green behavior. Such a company takes the initiative to assume environmental responsibility and sets up a good reputation on the society, in a way to reduce the possibility of pollution incidents and decreasing additional expenditures incurred therefrom [20]. As the company with strong profitability inputs more energy in environmental protection actions, it will gain more environmental and social benefits and competitive advantage. Therefore, we propose the following hypothesis:

$\mathrm{H} 2$ : profitability is strongly associated with company's green behavior.

\subsection{Development Ability and Green Behavior.} Development ability is a company's potential ability to extend its strength and scale, known as growth ability. It is also called the company's growth, referring to the development potential created by continuous accumulation and expansion of the company's operation and production activities [21]. While the company with development ability pursues economic profits, it will focus on building the company's social image and thus have a sense of social responsibility to comply with social ethics and order, from which the company can be more trusted by its partners and remembered by the mainstream market, thus leading to willingness to protect environment. Under such conditions, it will receive peers' social valuable resources and will increase efforts to energize environment-oriented production and process, which assists the company to save energy, reduce emissions, improve efficiency, decrease environmental costs, and achieve sustainable development; thereby, it will continuously enhance its competitive advantage in the long run and promote its more willingness to engage in green behavior in turn.

Furthermore, the company with development ability pays more attention to team building within the organization and form an environment-oriented cultural atmosphere. Environmental orientation is deemed as a critical respect of environmentalism [20] that presents the extent to which the company gets involved in overcoming environmental degradation [22]. In such a cultural atmosphere, the idea of environmental protection is embedded in daily routines of employees, and to promote employees to assume environmental responsibility with positive attitude, encourage employees' full participation in environmental protection activities where their environmental behavior is fostered [23]. Moreover, such a behavior will contribute to shaping an environmentally friendly image for the company on the society, expanding market share to increase sales, and giving rise to better profits eventually; thereby, it is beneficial to enhance the company's development ability. Thus, we propose the following hypothesis:

H3: development ability is strongly associated with company's green behavior.

2.4. Mathematical Measurement Model. According to statistical learning theory, support vector machine (SVM) is a method to optimize learning performance by adopting the idea of structural risk minimization. Its basic idea is to nonlinearly transform input data by means of kernel function, map input space to a space of high-dimension, and then receive optimal classification hyperplane in a space of high dimension. In fact, samples in classification problems are more easily separated in an accurate manner in highdimensional space than in low-dimensional space, which explains why support vector machine is easier to solve classification problems. Since data of financial indicators is spatially distributed in a very complex way, support vector machine is good at processing such data distributed spatially and complexly and is often used in the studies related to financial data $[11,12]$. Therefore, this article uses support vector machine as a judgment model to process financial index data and judge whether a company has green behavior. Support vector machine is a generalized linear classifier to carry out binary classification of data by means of supervised learning. Its classification form for a given dataset is

$$
f(x)=\langle w, \phi(x)\rangle .
$$

By adopting the regularized risk generalization principle, it can be obtained that

$$
R(w)=\frac{1}{2}\|w\|^{2}+C \sum_{i=1}^{m} L\left(f(x i), y_{i}\right),
$$

where $C$ is the penalty coefficient, $L$ is the loss function, and its expression is

$$
L(f(x), y)=\max \{|f(x)-y|-\varepsilon, 0\} .
$$

By minimizing $R(w)$, we can get

$$
w=\sum_{i=1}^{m}\left(\alpha_{i}-\alpha_{i}^{\prime}\right) \cdot \phi\left(x_{i}\right),
$$

where $\alpha_{i}, \alpha_{i}^{\prime}$ are Lagrangian multipliers. 
By substituting $w$ into equation (1), the following equation can be obtained:

$$
\begin{aligned}
f(x) & =\sum_{i=1}^{m}\left(\alpha_{i}-\alpha_{i}^{\prime}\right) \cdot\left\langle\phi\left(x_{i}\right) \cdot \phi(x)\right\rangle \\
& =\sum_{i=1}^{m}\left(\alpha_{i}-\alpha_{i}^{\prime}\right) \cdot k\left(x_{i}, x\right)+b,
\end{aligned}
$$

where $\sigma$ is the kernel function. In this article, the Gaussian kernel function is employed, and its expression is

$$
K\left(x_{i}, x\right)=\exp \left(\frac{-\left\|x_{i}-x\right\|^{2}}{2 \sigma^{2}}\right),
$$

where $\sigma$ is an adjustable parameter of Gaussian kernel function and $\left\|x_{i}-x\right\|$ represents the distance between two sample points.

2.5. Research Methodology. A mixed methodology is preferable in this study to clarify our understanding of the complex relationship mechanism of constructs. Quantitative and qualitative methods combined are ideal to generate clearer understanding of the mechanism that underlie quantitative outcomes in at least new territory partially [24]. Moreover, this approach is expected to help corroborate the results of both quantitative and qualitative analyses [25], in a way to provide better findings and improve reliability and validity [26]. The quantitative Study 1 is applied first to confirm the hypotheses and then followed by the qualitative Study 2 to explore selected cases.

\section{Quantitative Study 1}

3.1. Sample and Data Collection. Taking the concept of green behavior into account, this study selected samples according to the "List of Leading Central Enterprises in the Field of Energy Conservation and Environmental Protection" published by China Enterprise News. It considered companies which have achieved good green behavior effect in environmental protection by employing low-carbon and green production processes and transportation as green samples, involving high-tech companies in energy-saving and environmental protection, new energy, aerospace transportation equipment, and communication and electronic equipment industries, and then, 114 companies were selected from companies listed on Shanghai and Shenzhen stock markets.

In view of the range of samples selected, this study chose 114 manufacturing companies listed on Shanghai and Shenzhen stock markets in a ratio of $1: 1$ in areas of petroleum processing, coal mining, and chemical products as control samples, which were on the blacklist issued by the Ministry of Environmental Protection as a result of their poor green behavior in energy conservation and environmental protection. The data came from CSMAR database of Guo Tai'an and the CCER economic and financial database of Xenophon. By using the data of 14 financial indicators of business solvency, profitability, and development ability released from the 2019 annual report, we constructed a preliminary sample indicator system. The financial indicators are specifically reported in Table 1.

The prerequisite for judging financial indicators a company should have for good green behavior is that there must be significant differences in financial data. This study employed the $t$-test to perform significance testing for initial financial indicator system of all samples, with test results shown in Table 2. It was found that debt-to-tangible assets ratio $\left(X_{4}\right)$ failed the test at the level of $5 \%$, so that this variable was deleted. Additionally, other 13 financial indicators have all passed the test. To this end, this study selected 13 financial indicators as the final sample indicator system.

3.2. Experimental Design. This study aims at analyzing the complex relationship between financial performance and company's green behavior. Relying on the hypotheses proposed, financial indicators of business solvency, profitability, and development ability were gradually brought into the model to verify their accuracy and distinguish company's behavior. That is to say, first, one financial indicator of business solvency, profitability, and development ability was selected and put into the model, respectively, to calculate its judgment accuracy. Second, any two financial indicators out of business solvency, profitability, and development ability were selected to build a dataset, and then the dataset was put into the model to calculate the accuracy of its judgment. Finally, the data of all financial indicators was brought into the model to calculate the accuracy of its judgment. The results were compared and analyzed to determine the validity of financial indicators in judging if the company has green behavior.

For binary classification, it is easier to obtain optimal separating plane in the higher-dimensional feature space, while the core idea of SVM is to build an optimal separating hyperplane to enhance classification accuracy without complex mapping rules. Hence, we ultimately adopted Gaussian RBF Kernel as a kernel function after a series of experiments because of its best prediction results. Regularization parameter $C$ and kernel parameter $G$ are two important parameters set as 1. SVM model is described in detail in Table 3. In addition, by using a ten-fold cross-validation method for model training and verification, this study compared the optimal judgment results with MATLAB2015b as a tool for modeling analysis.

3.3. Evaluation Indicator Design. Three evaluation indicators referring to recall, precision, and accuracy were applied to compare the pros and cons of models. It was assumed that the company with good green behavior was marked positive value while the company with poor green behavior marked negative value. Specifically, the expressions of those three indicators were presented as follows: 
TABLE 1: Initial financial indicator system.

\begin{tabular}{|c|c|}
\hline Type & Financial indicators \\
\hline Business solvency & Current ratio $\left(X_{1}\right)$; quick ratio $\left(X_{2}\right)$; equity ratio $\left(X_{3}\right)$; debt-to-tar \\
\hline Profi & $\begin{array}{c}\text { Net profit rate of total assets }\left(X_{6}\right) \text {; return on equity }\left(X_{7}\right) \text {; cost and expense ratio }\left(X_{8}\right) \text {; return on total assets ratio }\left(X_{9}\right) \text {; } \\
\text { operating profit ratio }\left(X_{10}\right)\end{array}$ \\
\hline $\begin{array}{l}\text { Development } \\
\text { ability }\end{array}$ & $\begin{array}{l}\text { Growth rate of main income }\left(X_{11}\right) \text {; growth rate of total assets }\left(X_{12}\right) \text {; growth rate of net profit }\left(X_{13}\right) \text {; sustainable growth } \\
\text { rate }\left(X_{14}\right)\end{array}$ \\
\hline
\end{tabular}

TABLE 2: $t$-test of financial indicators.

\begin{tabular}{lccccccc}
\hline Financial indicator & $X_{1}$ & $X_{2}$ & $X_{3}$ & $X_{4}$ & $X_{5}$ & $X_{6}$ \\
\hline$t$ value & 14.831 & 13.437 & 9.672 & 1.022 & 10.310 & 20.883 \\
$P$ value & 0.000 & 0.000 & 0.000 & $0.308^{*}$ & 0.000 & 0.000 \\
\hline Financial indicator & $X_{8}$ & $X_{9}$ & $X_{10}$ & $X_{11}$ & $X_{12}$ & $X_{13}$ \\
$t$ value & 17.579 & 16.814 & 14.748 & 5.822 & 2.921 & 7.113 \\
$P$ value & 0.000 & 0.000 & 0.000 & 0.000 & 0.004 & 0.000 \\
\hline
\end{tabular}

Note: ${ }^{*}$ significance at the level of $5 \%$.

TABLE 3: The parameter settings of SVM.

\begin{tabular}{lcc}
\hline $\begin{array}{l}\text { Kernel function } \\
\text { type }\end{array}$ & $\begin{array}{c}\text { Regularization } \\
\text { parameter } C\end{array}$ & $\begin{array}{c}\text { Kernel parameter } \\
G\end{array}$ \\
\hline $\begin{array}{l}\text { Gaussian RBF } \\
\text { kernel }\end{array}$ & 1 & 1 \\
\hline
\end{tabular}

$$
\begin{aligned}
\text { recall } & =\frac{\mathrm{TP}}{\mathrm{TP}+\mathrm{FN}}, \\
\text { precision } & =\frac{\mathrm{TP}}{\mathrm{TP}+\mathrm{FP}}, \\
\text { accuracy } & =\frac{\mathrm{TP}+\mathrm{TN}}{\mathrm{TP}+\mathrm{FN}+\mathrm{FP}+\mathrm{TN}},
\end{aligned}
$$

where true positive (TP) stands for the number of positive samples that were classified as positive correctly, false negative (FN) for the number of positive samples that were misclassified as negative, false positive (FP) for the number of negative samples that were misclassified as positive, and true negative (TN) for the number of negative samples that were classified as negative correctly. All variables are reported in Table 4 .

3.4. Quantitative Analysis and Results. As described in experimental design, we first divided the data of financial indicators into 7 datasets, named Datasets 1 to 7 . Among them, Datasets 1 to 3 contain one of three financial indicators out of business solvency, profitability, and development ability in sequence, respectively, wherein Dataset 4 involves the data of business solvency and profitability, Dataset 5 consists of the data of business solvency and development ability, Dataset 6 includes the data of profitability and development ability, and Dataset 7 covers the data of 13 financial indicators in terms of all indicators. After conducting many experiments, the SVM model with radial basis kernel function was capable of obtaining optimal judgment results. Thus, this study adopted it as the judgment model, and then 7 datasets were taken into the SVM model.
TABLE 4: Meaning of four variables.

\begin{tabular}{lcc}
\hline & Classified positive & Classified negative \\
\hline Actually positive & TP & FN \\
Actually negative & FP & TN \\
\hline
\end{tabular}

The results of Datasets 1 to 3 are presented in Table 5; results of Datasets 4 to 6 are presented in Table 6 . Table 7 reports the mean values of Dataset 7 and the first two groups.

Comparing the results in Table 5, three types of financial indicators were put into the model, respectively, and the results obtained were very similar. Three indicators of Dataset 2 were similar, of which accuracy was the best, with a value of $67.35 \%$. The results of these comparisons are shown in Figure 1. The mean values of three financial indicators were calculated to be $69.44 \%, 62.75 \%$, and $64.63 \%$, respectively. Then, comparing the results in Table 6 , the results of Datasets 4 to 6 were very similar, but they were all better than the results of the first three datasets.

Among the results of Datasets 4 to 6 , the best one is Dataset 4 , whose accuracy was $81.63 \%$. These comparative results are shown in Figure 2. The mean values of these three datasets were $79.17 \%, 76.25 \%$, and $77.55 \%$, respectively. Last, we compared the mean values of the first two kinds of data with the results of Dataset 7 (all data of financial indicators), as shown in Table 7 , the prediction result was the best regardless of which indicator, namely, 95.83\%, 82.14\%, and $87.76 \%$, respectively. This is also shown in Figure 3 that the column of each indicator is the highest. From these judgment results, we can make it clear that each type of financial indicator can be used to judge whether the company has green behavior; it will achieve better result if the company's green behavior is rated through combining these three types of financial indicators.

3.5. Brief Discussion. In the quantitative Study 1, the experimental results are consistent with the hypotheses proposed, but to further explore why, this study conducted a number of follow-up interviews with typical enterprises with 
TABLE 5: Results of SVM model for Datasets 1-3.

\begin{tabular}{lccc}
\hline Dataset & Recall & Precision & Accuracy \\
\hline Dataset 1 & 70.83 & 62.96 & 65.31 \\
Dataset 2 & 66.67 & 66.67 & 67.35 \\
Dataset 3 & 70.83 & 58.62 & 61.22 \\
Mean 1 & 69.44 & 62.75 & 64.63 \\
\hline
\end{tabular}

TABLE 6: Results of SVM model for Datasets 4-6.

\begin{tabular}{lccc}
\hline Dataset & Recall & Precision & Accuracy \\
\hline Dataset 4 & 79.17 & 82.61 & 81.63 \\
Dataset 5 & 75.00 & 69.23 & 71.43 \\
Dataset 6 & 83.33 & 76.92 & 79.59 \\
Mean 2 & 79.17 & 76.25 & 77.55 \\
\hline
\end{tabular}

TABLE 7: Results of SVM model for Dataset 7 and mean values.

\begin{tabular}{lccc}
\hline Dataset & Recall & Precision & Accuracy \\
\hline Dataset 7 & 95.83 & 82.14 & 87.76 \\
Mean 1 & 69.44 & 62.75 & 64.63 \\
Mean 2 & 79.17 & 76.25 & 77.55 \\
\hline
\end{tabular}

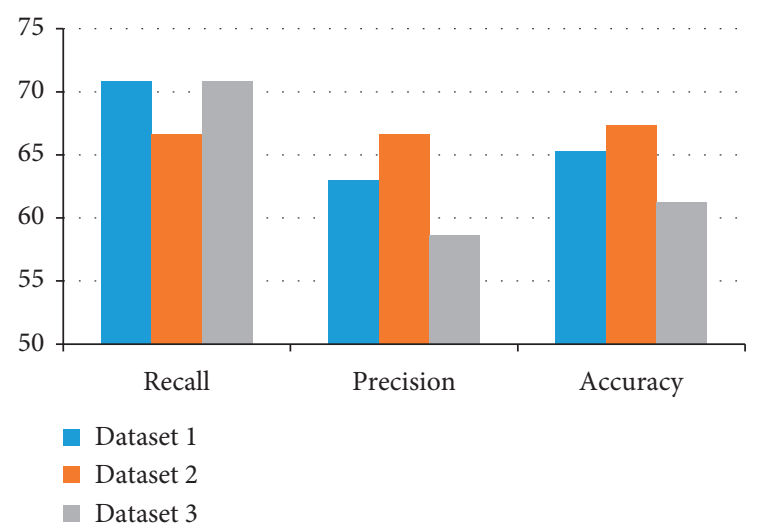

Figure 1: Comparison of judgment results among Datasets 1-3.

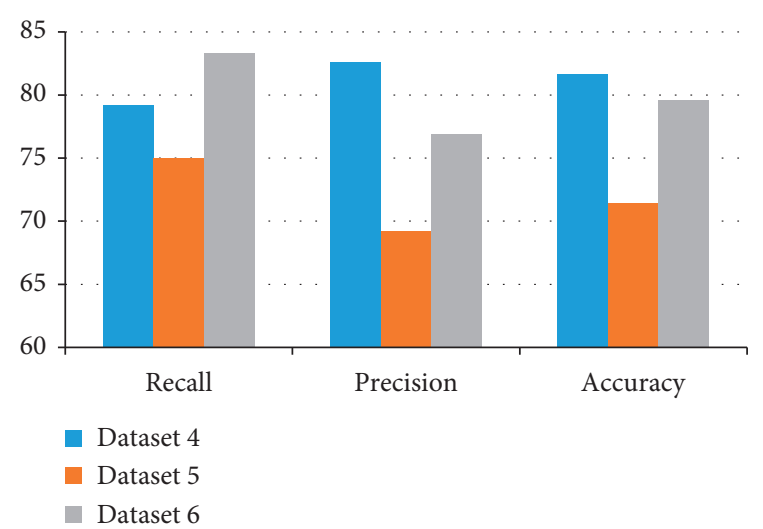

FIgURE 2: Comparison of judgment results among Datasets 4-6.

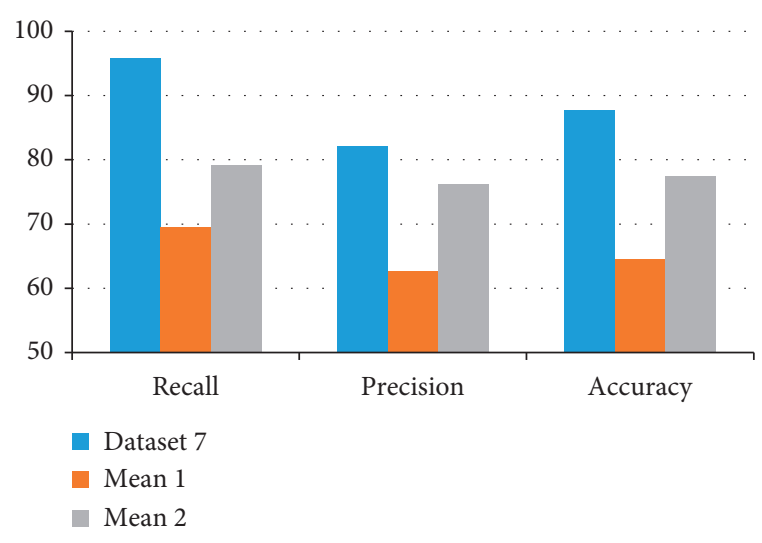

Figure 3: Comparison of judgment results among Dataset 7 and mean values.

good or bad green behaviors in different industries to investigate the underlying mechanism of the above relationships.

\section{Qualitative Study 2}

4.1. Sample and Data Collection. In the qualitative Study 2, this article adopts a case study approach to reveal the relationship mechanism linking financial indicators and company's green behavior. In order to conduct in-depth comparative analysis, this study selected 64 employees of ten enterprises $\left(\mathrm{A}^{+}-\mathrm{J}^{+}\right)$with good green behavior on the "List of Leading Central Enterprises in the Field of Energy Conservation and Environmental Protection" and 61 employees of ten enterprises $\left(\mathrm{A}^{--} \mathrm{J}^{-}\right)$with bad green behavior on the blacklist as final interviewees. We chose senior executives, managers, and employees primarily involved in environmental practices, with an assistance of documentation of those cases. By applying nonstandardized interviews (semistructured and in-depth), we gathered better replies to "why" issues in case study. The departments involved referred to finance, strategic planning, intelligence and standardization, and general management. Each interview lasted 1.5 to 2 hours.

4.2. Data Analysis. Following data analysis of Miles et al., we began our study with a specific thematic analysis of interview transcripts, from which we identified common categories compared to those constructs included in our theoretical model. Followed by a second-cycle coding for identifying patterns, our initial coding was conducted with analysis of every case, so as to capture all expressions of phenomena and explain them in view of extant concepts, i.e., financial indicators and green behavior. Codes regarding the impact of financial indicators on green behavior emerged via a continuous comparison between data newly gathered and that collected previously and their coding. Then, coding deductively began with reviewing extant literatures on financial indicators and green behavior and then extended into inductive interpretation according to additional information 
given data of interviews and display of all findings [27]. Categories were formed and refined after the association between text coded previously, and codes created newly were checked. Emergent codes and connections among all categories give rise to variables identified, such as three dimensions of financial indicators, and their interpretation of data of interviews caused reoccurring patterns identified, resulting in green behavior process. Data collection, data analysis, and conceptualization process were constantly overlapped [28] until the relationship between concepts emerged and reached theoretical saturation. Further, to avoid potential bias of respondents, our study put emphasis on both narrative openness and guarantee of problems to be accurately presented.

4.3. Qualitative Analysis and Results. The findings indicated that respondents from companies with good green behaviors agreed that all three financial indicators were associated with their respective corporate green behaviors, as shown in Table 8. Otherwise, for companies with bad green behaviors, these three financial indicators had relatively weak effects on the development of their green behaviors. From the interviews, it was also learned that three financial indicators promoted the development of companies and their environmental protection behaviors, for the reason that when a company's financial situation was good, it would pay more attention to corporate social responsibility and social image and would further develop environmental protection behaviors; second, a company's good financial status signified that it could win profits only if its products were sold well on the market, so that the company would like to develop environmentally friendly products and take active green measures, thereby being more willing to perform environmental protection behaviors.

In business solvency, companies with strong business solvency were more likely to be favored by financial institutions due to their stable operation, economic power, good reputation, and financial status and hence, they were more motivated to foster green behaviors. In companies with good green behaviors, respondents all believed business solvency has an impact on company's green behavior, because it is to manifest a company's economic strength so that the company is confident to mobilize long-term and short-term funds to ensure sound business development. It is understood the stronger the solvency is, the enhanced ability the company has to operate steadily. For instance, interviewees in Company $\mathrm{E}^{+}$pointed out that their company quickly received financial support from partners for an aim of launching a large technology development project, which is beneficial to the production of new green products. Interviewees in Company $\mathrm{B}^{+}$explained that their company emphasized social reputation and corporate image, so it is often a foregoer in environmental protection. Otherwise, in companies with bad green behaviors, interviewees believed to fail to get loans or receive any other investments, or their company was not operated well with low business volume and capital flow, so it did expose disadvantages in business solvency. Hence, they had no money to engage in environmentally friendly product development, and even there would be no time for green behavior.

In profitability, respondents thought that their company had strong profitability, good financial status, and good reputation in society and catered to consumers' demand for green products, so they had initiative to invest in green productivity. In companies with good green behaviors, interviewees were unanimous that the more profitable the businesses were, the more they would strengthen green behavior to give back to the society. Interviewees in Company $\mathrm{C}^{+}$argued that the increase in profitability led to investing more in environmental protection and optimizing green behavior. For example, increasing utilization rate of green resources is to indirectly decrease corporate pollution control costs and potential fines. Interviewees in Company $\mathrm{F}^{+}$put forward that all companies underlined the development of green products. The greener the products, the higher the sales, then the more increased the revenue, so that their company would be more willing to invest in practices for green behavior.

In companies with bad green behaviors, interviewees made a point that their company had no instant abilities to carry out green behavior due to low profits available and wage coefficient turned down. Interviewees in Company $\mathrm{B}^{-}$ indicated that environmental cost accounts for higher proportion in total manufacturing cost, which decreased their profit margins and ultimately led to competitive disadvantage. In this sense, their company would not like to increase environmental input as it was considered an additional cost. Interviewees in Company $\mathrm{I}^{-}$described that if they increased the investment in human, material, and financial resources in environmental protection, this would inevitably affect their company's operations and distribution of revenue.

In development ability, respondents mentioned that they laid emphasis on cultivating their own long-term development potential and social and environmental responsibilities, on delivering green development concept to employees within the organization, and thus indoctrinating them with environmental ideas. In companies with good green behaviors, interviewees explained that green development was required by an objective of current social and economic development. Sometimes, companies that had long-term and promising development insisted on facing up to environmental protection issues, so they would be willing to perform green behaviors voluntarily. Interviewees in Company $\mathrm{I}^{+}$believed that their company with strong development ability was willing to give back to the society and consumers, so they had a sense of social responsibility, including environmental protection and social ethics. Accordingly, they would like to have green behaviors. In companies with bad green behaviors, interviewees suggested that their companies had less development ability, sometimes in lack of money or resources to develop green behaviors, so it caused less benefits obtained. Interviewees in Company $\mathrm{J}^{-}$mentioned that their company was criticized by name and received a fine because of their improper waste disposal a while ago. Interviewees in Company $\mathrm{C}^{-} \mathrm{em}^{-}$ phasized that their company's development ability was not 
TABLE 8: Evidence from data illustrating major relationships between financial indicators and company's green behavior.

\begin{tabular}{|c|c|c|}
\hline Typical quotes from interviews & & Insight \\
\hline $\begin{array}{l}\text { Companies with } \\
\text { good green } \\
\text { behaviors }\end{array}$ & $\begin{array}{l}\text { "Business solvency is often a key factor in } \\
\text { measuring a company's reputation in society, } \\
\text { standing for credibility in society. The company } \\
\text { with strong business solvency tends to take good } \\
\text { care of their reputation, so they will actively } \\
\text { participate in green practices." (Company } \mathrm{E}^{+} \text {) } \\
\text { "The company has strong business solvency, } \\
\text { implying that it has the ability to repay debt, has } \\
\text { economic development potential, and will also } \\
\text { establish green behaviors to enhance trust } \\
\text { between partners." (Company } \mathrm{C}^{+} \text {) } \\
\text { "Our company has no debts in arrears, but has } \\
\text { stable and good operating efficiency, and has a } \\
\text { high reputation in the industry. It is well known } \\
\text { that our company is a role model in green } \\
\text { behavior area, and is the first to apply many } \\
\text { environmental protection measures." (Company } \\
\text { "G }{ }^{+} \text {) } \\
\text { "The company that has long-term debts must be } \\
\text { the one in poor financial condition. Such a } \\
\text { company often has poor prospects, so that it will } \\
\text { think more about their own interests rather than } \\
\text { their contributions to environmental causes." } \\
\text { (Company B }{ }^{-} \text {) } \\
\text { "Our company has been good in green practices } \\
\text { before, and has invested a lot in the development } \\
\text { of green innovative products, but recently some } \\
\text { problems have occurred in capital chain, causing } \\
\text { debts not to be repaid in time, so green products } \\
\text { developed have to be terminated, which hinders } \\
\text { our green behavior." (Company D } \text { ) } \\
\text { development in large-scale heavy industry, so we } \\
\text { have debts not repaid as there has been no return } \\
\text { of funds before we sell our products out, I am } \\
\text { afraid we have no power to care about green } \\
\text { behavior. (Company } \mathrm{C}^{-} \text {) }\end{array}$ & $\begin{array}{c}\text { Business solvency is strongly associated with } \\
\text { company's green behavior in terms of its favor } \\
\text { by financial institutions, stable operation, } \\
\text { economic power and financial status, and good } \\
\text { reputation. }\end{array}$ \\
\hline
\end{tabular}


TABle 8: Continued.

\begin{tabular}{|c|c|c|}
\hline Typical quotes from interviews & & Insight \\
\hline $\begin{array}{c}\text { Companies with } \\
\text { good green } \\
\text { behaviors }\end{array}$ & 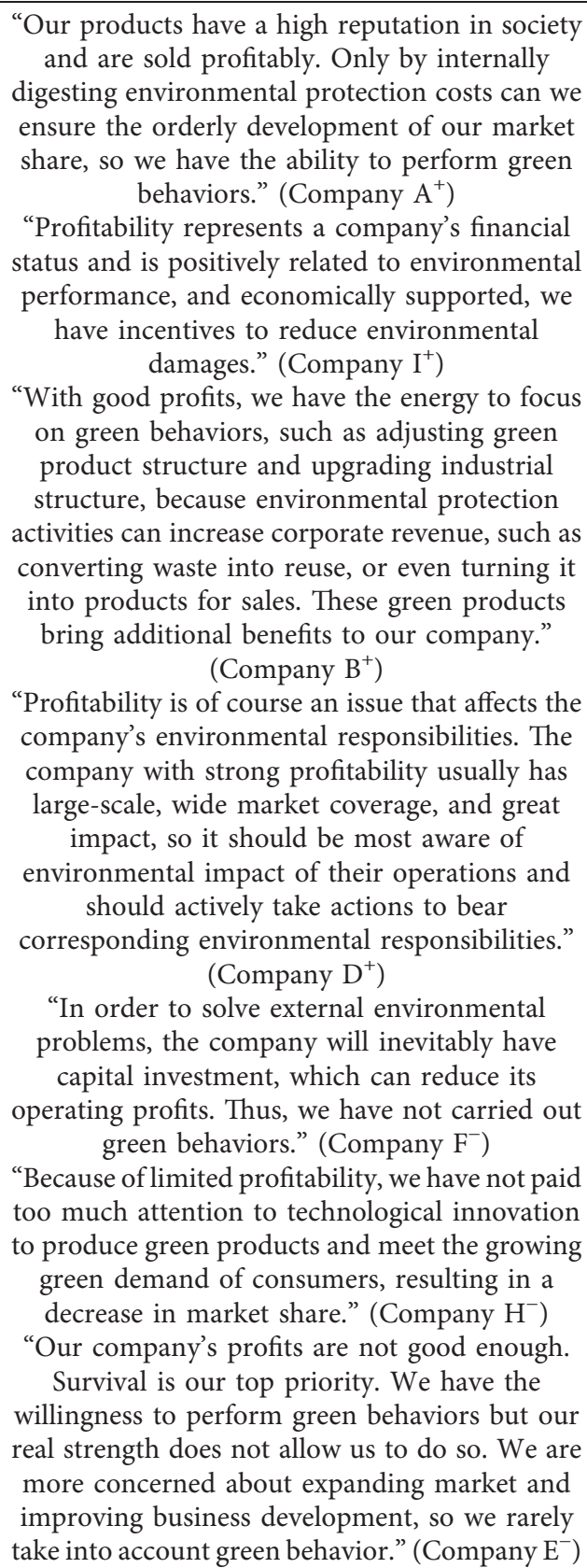 & $\begin{array}{l}\text { Profitability is strongly associated with } \\
\text { company's green behavior in terms of its good } \\
\text { reputation, financial status, initiative to invest in } \\
\text { green productivity, and social and } \\
\text { environmental responsibilities. }\end{array}$ \\
\hline
\end{tabular}


TABle 8: Continued.

\begin{tabular}{|c|c|c|}
\hline Typical quotes from interviews & & Insight \\
\hline $\begin{array}{c}\text { Companies with } \\
\text { bad green } \\
\text { behaviors }\end{array}$ & $\begin{array}{l}\text { "Our development prospects are very optimistic, } \\
\text { we have always had a sense of social and } \\
\text { environmental responsibilities. We have a good } \\
\text { image in society and are willing to set an example } \\
\text { in environmental protection decisions and } \\
\text { behaviors." (Company } \mathrm{H}^{+} \text {) } \\
\text { "From a long-term development perspective, it is } \\
\text { an inescapable responsibility for our company to } \\
\text { participate in environmental protection } \\
\text { practices. Therefore, we decompose the } \\
\text { performance of green behaviors within the } \\
\text { company and distribute it to every employee, so } \\
\text { that everyone is responsible for green behavior." } \\
\text { (Company I }{ }^{+} \text {) } \\
\text { "Our company has relatively weak development } \\
\text { ability, for those with strong abilities, they are } \\
\text { obliged to return to the market and to the society } \\
\text { with healthier and green products, but we have } \\
\text { not done enough at this point." (Company } \mathrm{D}^{-} \text {) } \\
\text { "The development prospects we face and our } \\
\text { existing development ability limit our vision for } \\
\text { future development in every respect. For us, } \\
\text { following the original supply chain activities will } \\
\text { bring us the same benefits as before, but we are } \\
\text { also trying to change to cater to environmental } \\
\text { protection. but it is impossible to achieve rapid } \\
\text { change of concept in a short period." (Company } \\
\text { A } \text { (Company }{ }^{-} \text {) } \\
\text { "Our development ability has not yet made it } \\
\text { possible for us to immediately focus on the } \\
\text { development of green behavior, because this } \\
\text { requires a transformation from the inside to the } \\
\text { outside. First, our company has not set off such a } \\
\text { green atmosphere to employees. Second, we have } \\
\text { no suppliers to provide environmentally friendly } \\
\text { resources. These may be determined by our } \\
\text { original heavy industry development route." } \\
\text { (Coum }\end{array}$ & $\begin{array}{l}\text { Development ability is strongly associated with } \\
\text { company's green behavior in terms of its social } \\
\text { and environmental responsibilities, long-term } \\
\text { development potential, and providing } \\
\text { environmental ideas to employees. }\end{array}$ \\
\hline
\end{tabular}

prominent, they were weakly aware of obligation and responsibilities for future development, and thus, that was the reason that they were unable to actively perform green behaviors.

4.4. Brief Discussion. In Study 2, the results are consistent with those in Study 1, verifying H1, H2, and H3. More importantly, the longitudinal case studies revealed new findings of the underlying relationship mechanism between variables, as depicted in Figure 4 . The frame reports that three financial indicators have different influences on company's green behaviors through diverse channels and also, to adapt to the development trend of the times, companies actively start green activities to implement green behaviors and meet green needs of stakeholders so as to win their support, this is conducive to companies' long-term construction of competitive advantage as their green strategic objectives will provide them with a large number of business opportunities. For example, in this case, some profitable companies that embarked money in pollutionreducing processing equipment achieve competitive advantages; by means of brand recognition and customer loyalty, they can perfect their products towards higher quality of environmental protection, decreased pollution to the environment, and balance of the relationship between corporate economic benefits and the environment. Hence, these companies will keep sustainable competitive advantages in the long run.

In a similar way, when companies undertake a series of environmental management measures to upgrade the quality of environmental assets for production in supply chain, all moves satisfy market value conditions with unique, irreplaceable, and nonimitable green products, thus 


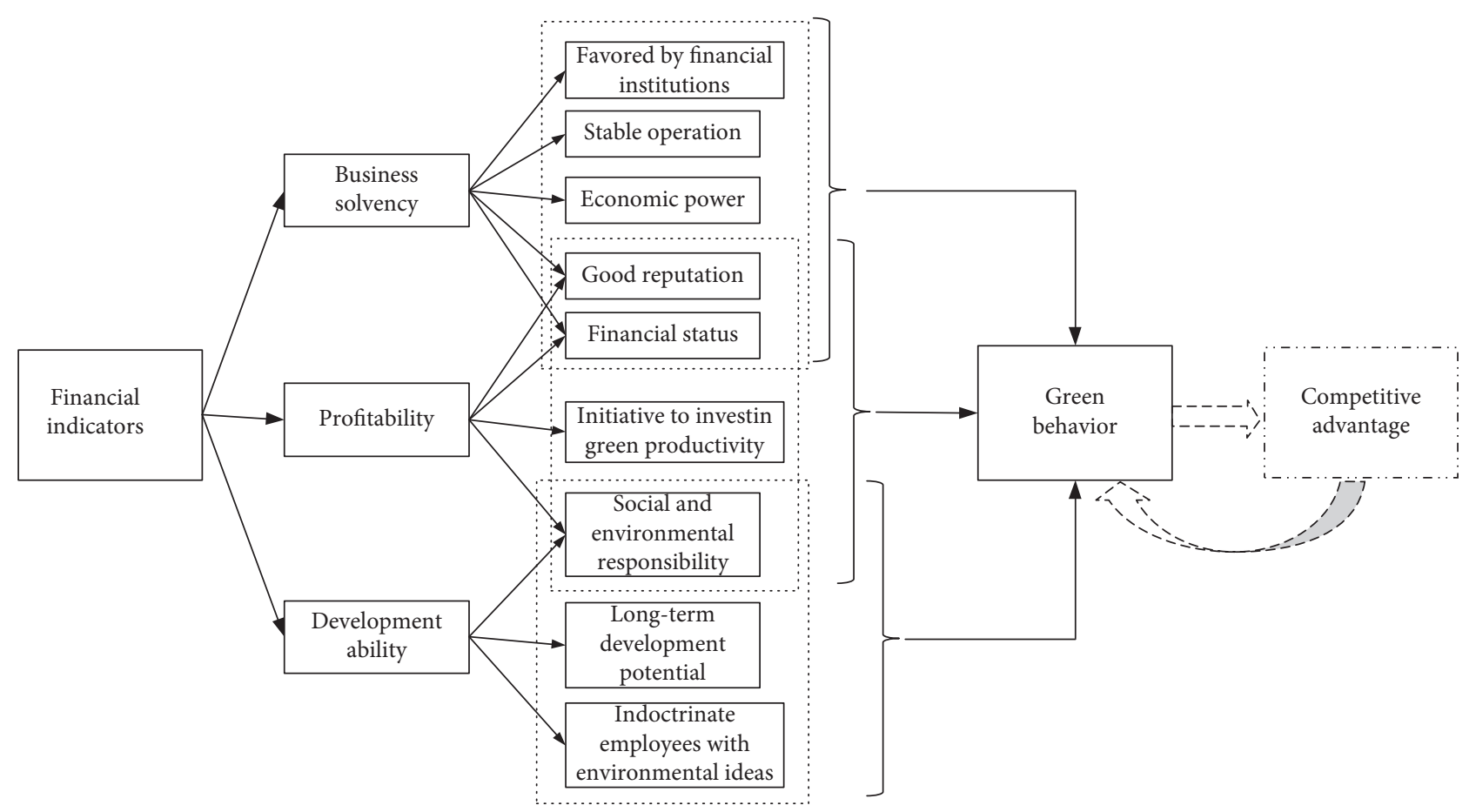

Figure 4: The relationship mechanism between variables.

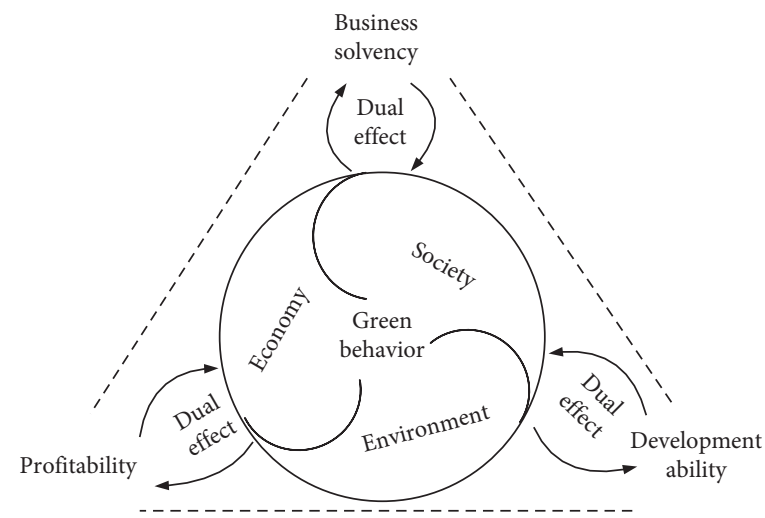

FIgURE 5: Dual effect among variables.

improving companies' three financial indicators in diverse ways in turn. Finally, it secures green behavior quality and elevates it to a higher level.

\section{Discussion and Conclusion}

This article adopts the mixed methodology to investigate the complex relationships mechanism between key financial indicators and company's green behavior with a sample of companies with good or bad green behaviors for a comparative analysis. The results show that business solvency, profitability, and development ability are strongly associated with company's green behavior, respectively.

The three financial indicators selected in this article are all key indicators of corporate financial status, reflecting enterprise development and operational stability. This study analyses their impact on company's green behavior from different perspectives. The findings of this study are in line with the existing research trend that a company's financial status affects whether it is engaged in environmental protection and development [23], implying that companies will be committed to engaging in environmentally responsible and economical operations while acknowledging stakeholders' interests and will, and also, to improve company's reputation; companies will take efficient advantage of resources to lower raw material costs and reduce possible pollution costs and fines. This confirms to the result that when companies consider environmental protection incidents in the long run, they will deliver environmentally friendly products to customers, so that they can increase market share and/or charge higher price for their products [15]. From this, companies' environmental protection or green behavior will become a potential source of corporate competitive advantage $[29,30]$. 
Combined with the findings of this study, it can be found that our results show a dual-effect relationship between financial performance and corporate green behavior. Specifically, when companies are in pursuit of better environmental practices, their brand profile and social image will be raised up to let them be trusted by more stakeholders in the society and further, they will take more social responsibilities and realize higher work efficiency for consumers and for their economic benefits. As a result, our findings also demonstrate the bidirectional and cyclical relationship effect among environment, society, and economy, as shown in Figure 5. This is in line with existing researches. For example, Walter [31] and Woolman and Veshagh [32] believed that environmental and economic benefits can be effectively integrated. Our findings also broaden the dimensions of their relationship among environment, economy, and society rather than the prior two.

In summary, through the circular effect depicted in Figure 5, as corporate competitive advantage or financial performance can be improved sustainably, it will inevitably intensify the driving force of green behavior and improve its quality. In this way, our findings corroborate the studies of Abdul and Mohammad [19] who argued that financial development stimulates environmental quality and environmental development in different countries.

5.1. Theoretical Implications. Our study has several theoretical implications to the extant literature; in particular, it makes up for deficiency of most studies that are only conducted in developed countries [13]. As environmental problems become global in scope and environmental management in companies is getting more attention in developing countries, our results first contribute to the green behavior literature by applying a mixed methodology to investigate the complex relationship mechanism between financial performance and company's green behavior with a comparative study, wherein support vector machine which has good performance to process financial indicators is used as a mathematical model method in the quantitative study.

Second, this study extends the green behavior literature by examining the impact of financial performance on corporate green behavior/environmental behavior as currently many scholars have investigated how firms are financially rewarded for improving environmental behavior [33]. Specifically, our study differentiates how business solvency, profitability, and development ability affect company's green behavior based on environment, economy, and society perspectives. Hence, our findings complement the sustainability literature that has been discussed recently as a crosssectional character, following the socioeconomic trend of sustainable development [34].

Third, this study contributes to the green behavior literature by extending the researches regarding financial development-environmental quality [19] and by providing an additional proof to debate on the effect on financial development on environmental quality [34]. More specifically, our findings reveal environmental quality can be improved ultimately after the driving force of green behavior is intensified by financial indicators or by competitive advantage resulting therefrom. Our findings confirm the conclusions that believe financial development is able to promote environmental development and quality [35, 36], but are contradictory to the studies insisting on no effect between them $[37,38]$.

5.2. Practical Implications. The findings of this study have several practical implications for managers in companies that pursue green behaviors. First, our results show that business solvency, profitability, and business ability are major drivers of company's green behavior, leading to environmental quality improved in dual ways. Companies can emphasize the complex two-way relationship to improve environmental development while pursuing economic interests. Second, our study takes into account the integration perspectives of environment, economy, and society, so companies can make more effort in assuming responsibility for environmental protection with an increase of investment in green practices, because they can prevent from suffering negative exposure by media, penalties fined by government, and shareholder boycotts, but also achieve both social reputation and better economic benefits in the long run.

5.3. Limitations and Future Research Directions. While this study provides valuable insights for research and practice, it suffers from several limitations. First, our study only selects three key variables of financial performance to investigate how they influence company's green behavior. Further research is encouraged to analyse other specific variables that may explain company's green behavior as well in the same context, i.e., long-term or short-term solvency and operational capacity. Second, this study applies the mathematical measurement model to verify the hypotheses proposed. Further research can strive for using other empirical methods to test hypotheses in this study as well as its credibility and extend scope of its application. Third, this study adopts the method of comparative analysis to explore the complex relationships, so that further researches can carry out similar analysis in certain category of enterprises from different perspectives and thus to form systematic and complete longitudinal studies.

\section{Data Availability}

The financial indicator data used to support the findings of this study are available from the corresponding author upon request.

\section{Conflicts of Interest}

The authors declare that they have no conflicts of interest regarding the publication of this paper.

\section{Acknowledgments}

This work was supported by the National Natural Science Foundation of China (Grant no. 71801187), Humanities and 
Social Sciences Research Project of the Ministry of Education of China (no. 20YJC630218), China Scholarship Council (CSC) (no. 202008370107), Special Project of Shandong Province Social Science Planning Social Science Popularization Application Research (no. 19CKPJ07), and Shandong Key Research and Development Plan (Major Scientific and Technological Innovation Project) (no. 2018CXGC0703).

\section{References}

[1] M. Binder and A.-K. Blankenberg, "Green lifestyles and subjective well-being: more about self-image than actual behavior?" Journal of Economic Behavior \& Organization, vol. 137, pp. 304-323, 2017.

[2] S. Sihvonen and J. Partanen, "Implementing environmental considerations within product development practices: a survey on employees' perspectives," Journal of Cleaner Production, vol. 125, pp. 189-203, 2017.

[3] A. R. Abban and M. Z. Hasan, "The causality direction between environmental performance and financial performance in Australian mining companies - a panel data analysis," Resources Policy, vol. 70, Article ID 101894, 2021.

[4] F. Wu, S. Yeniyurt, D. Kim, and S. T. Cavusgil, "The impact of information technology on supply chain capabilities and firm performance: a resource-based view," Industrial Marketing Management, vol. 35, no. 4, pp. 493-504, 2006.

[5] S. El Ghoul, O. Guedhami, C. C. Y. Kwok, and D. R. Mishra, "Does corporate social responsibility affect the cost of capital?" Journal of Banking \& Finance, vol. 35, no. 9, pp. 2388-2406, 2011.

[6] N. Muhammad, F. Scrimgeour, K. Reddy, and S. Abidin, "The relationship between environmental performance and financial performance in periods of growth and contraction: evidence from Australian publicly listed companies," Journal of Cleaner Production, vol. 102, pp. 324-332, 2015.

[7] R. Yu and Q. Zhu, "The present and future of enterprise environmental behavior," Journal of Industrial Technological Economics, vol. 28, no. 8, pp. 2-6, 2009.

[8] S. Zhou, "Research on influencing factors of enterprise's environmental behavior," Statistics \& Decision, vol. 22, pp. 181-183, 2011.

[9] G. E. Greenley and R. F. Gordon, "Multiple stakeholder orientation in UK companiesand the implications for company performance," Journal of Management Studies, vol. 5, no. 34, pp. 259-284, 1997.

[10] S. Schaltegger, R. Burritt, and H. Petersen, An Introduction to Corporate Environmental Management: Striving for Sustainability, pp. 541-542, Emerald Group Publishing Limited, Sheffield, UK, 2003.

[11] S. Choudhury, S. Ghosh, A. Bhattacharya, K. J. Fernandes, and M. K. Tiwari, "A real time clustering and SVM based pricevolatility prediction for optimal trading strategy," Neurocomputing, vol. 131, no. 5, pp. 419-426, 2014.

[12] M. Z. Abedin, C. Guotai, F.-E. Moula, A. S. M. S. Azad, and M. S. U. Khan, "Topological applications of multilayer perceptrons and support vector machines in financial decision support systems," International Journal of Finance \& Economics, vol. 24, no. 1, pp. 474-507, 2018.

[13] K. Nishitani, N. Jannah, S. Kaneko, and Hardinsyah, "Does corporate environmental performance enhance financial performance? An empirical study of Indonesian firms," Environmental Development, vol. 23, pp. 10-21, 2017.
[14] M. S. Freedman, "Disclosure of environmental cleanup costs: the impact of the Superfund act," Advances in Public Interest Accounting, pp. 163-165, 1995.

[15] M. Khanna, W. R. H. Quimio, and D. Bojilova, "Toxics release information: a policy tool for environmental protection," Journal of Environmental Economics and Management, vol. 36, no. 3, pp. 243-266, 1998.

[16] D. Gregory-Smith, D. Manika, and P. Demirel, "Green intentions under the blue flag: exploring differences in EU consumers' willingness to pay more for environmentallyfriendly products," Business Ethics: A European Review, vol. 26, no. 3, pp. 205-222, 2017.

[17] H. Wu, Construction Engineering Economics, Building Industry Press, Haidian, China, 2014.

[18] M. A. Soytas, M. Denizel, and D. Durak Usar, "Addressing endogeneity in the causal relationship between sustainability and financial performance," International Journal of Production Economics, vol. 210, pp. 56-71, 2019.

[19] R. A. Abdul and Z. H. Mohammad, "The causality direction between environmental performance and financial performance in Australian mining companies-a panel data analysis," Resources Policy, 2020.

[20] M. P. Sharfman and C. S. Fernando, "Environmental risk management and the cost of capital," Strategic Management Journal, vol. 29, no. 6, pp. 569-592, 2008.

[21] K. Liu and X. Ma, "Evaluation of development capability of small- and medium-sized high-tech enterprises," Journal of Hubei Radio \& Television University, pp. 85-87, 2005.

[22] E. Fraj-AndrésEva, E. Martínez-Salinas, and J. Matute-Vallejo, "Factors affecting corporate environmental strategy in Spanish industrial firms," Bus. Strat. Environ.vol. 18, no. 8, pp. 500-514, 2009.

[23] Y. Yu and B. Huo, "The impact of environmental orientation on supplier green management and financial performance: the moderating role of relational capital," Journal of Cleaner Production, vol. 211, pp. 628-639, 2019.

[24] A. Edmondson and S. McManus, "Methodological fit in management Field research," Academy of Management Review, vol. 32, no. 4, pp. 1155-1179, 2007.

[25] M. Saunders, P. Lewis, and A. Thornhill, Research Methods for Business Students, Pearson Education Limited, Harlow, UK, 5th edition, 2009.

[26] A. Bryman and E. Bell, Business Research Methods, Oxford University Press, Oxford, UK, 3rd edition, 2011.

[27] M. B. Miles and A. M. Huberman, Qualitative Data Analysis. An Expanded Sourcebook, SAGE, Thousand Oaks, CA, USA, 1994.

[28] T. D. Jick, "Mixing Qualitative and quantitative methods: triangulation in action," Administrative Science Quarterly, vol. 24, no. 4, pp. 602-611, 1979.

[29] D. Earnhart, "Effects of permitted effluent limits on environmental compliance levels," Ecological Economics, vol. 61, no. 1, pp. 178-193, 2007.

[30] S. Adams and E. K. M. Klobodu, "Financial development and environmental degradation: does political regime matter?" Journal of Cleaner Production, vol. 197, pp. 1472-1479, 2018.

[31] I. Walter, "The pollution content of American trade," Economic Inquiry, vol. 11, no. 1, pp. 61-70, 1973.

[32] T. Woolman and A. Veshagh, "Development of management tool for assessing environmental performance in SMEs' design and production," in Proceedings of the 14th CIRP Conference on Life Cycle Engineering, pp. 383-388, Tokyo, Japan, June 2007. 
[33] M. A. Delmas, N. Nairn-Birch, and J. Lim, "Dynamics of environmental and financial performance: the case of greenhouse gas emissions," Organization \& Environment, vol. 28 , no. 4 , pp. $374-393$.

[34] A. A. Olufemi and A. O. Adefemi, "Financial development and environmental quality in sub-Saharan Africa:Is there a technology effect?" Science of the Total Environment, vol. 747, Article ID 141515, 2020.

[35] M. A. Nasir, T. L. Xuan Tram, and H. T. X. Tram, "Role of financial development, economic growth \& foreign direct investment in driving climate change: a case of emerging ASEAN," Journal of Environmental Management, vol. 242, pp. 131-141, 2019.

[36] U. Al-Mulali, C. F. Tang, and I. Ozturk, "Does financial development reduce environmental degradation? Evidence from a panel study of 129 countries," Environmental Science and Pollution Research, vol. 22, no. 19, pp. 14891-14900, 2015.

[37] E. Dogan and B. Turkekul, " $\mathrm{CO}_{2}$ emissions, real output, energy consumption, trade, urbanization and financial development: testing the EKC hypothesis for the USA," Environmental Science and Pollution Research, vol. 23, no. 2, pp. 1203-1213, 2016.

[38] A. Jalil and M. Feridun, "The impact of growth, energy and financial development on the environment in China: a cointegration analysis," Energy Economics, vol. 33, no. 2, pp. 284-291, 2011. 